DOI: $10.30525 / 978-9934-588-61-7-13$

Savchuk O. O.

Ph.D, Assistant of the Department of Environmental Law, Yaroslav Mudryi National Law University, Research Associate, Research Institute for Legal Support for Innovative Development of the National Academy of Law Sciences of Ukraine

Matvieieva A. V. Ph.D., Senior Researcher, Associate Professor at the Department of Law National Aerospace University H.E. Zhukovsky «Kharkiv Aviation Institute»

\title{
LEGAL REGULATION OF ENTREPRENEURSHIP IN THE CONTEXT OF THE DEVELOPMENT OF NATIONAL ECONOMY
}

\section{Summary}

The paper analyzes the issues of legal regulation of entrepreneurship in the context of building the national economy. The current legislation is analyzed, including legal documents that will regulate business activities during the pandemic caused by the coronavirus disease COVID-19. The problems that cause conflicts in the legislation and ways to level them are described. Emphasis is placed on the need to develop an effective settlement mechanism on business issues. It is noted that the regulation of entrepreneurial activity and the lack of transparent mechanisms of interaction between public authorities and entrepreneurs inhibits the development of entrepreneurship. It is noted that the development and support of small and medium-sized businesses requires the development of an effective implementation mechanism by the state, starting with the regulation and effectiveness of regulations and ending with financial assistance and a simplified tax system. And this applies not only to the quarantine period in the state, but their introduction on a permanent basis. Emphasis is placed on the need to establish tax benefits, including tax credits, tax holidays, etc.

\section{Introduction}

The guidelines of the legal, democratic and social state defined in the Constitution of Ukraine and the objective need for dynamic development of the state are closely connected with ensuring the reform of the business management system. This process is a necessary element of the current stage of state formation, as the nature and degree of success of this process determines not only the democracy of state-building transformations, but also the effectiveness of the entire economic system of the country. Entrepreneurial activity is an integral attribute of the market economy of the 
country, the development of which is determined by the state and level of market relations, that is, favorable and necessary conditions for the functioning of the private sector in the economy, and the result is to stimulate productivity, obtain the desired profit and meet social needs.

The state influences entrepreneurial activity in many ways: through planning, stimulating research, production, marketing, and others. Peculiarities of state regulation of business entities depend on the specific field of business, the size of the business entity, its location, the type of products, the characteristics of the market where it operates.

The main way, in which the state regulates in the field of entrepreneurship, is the issuance of regulations governing the activities of entrepreneurs. Laws and other regulations create the necessary legal regime to ensure the public interest in the economy. The objects of protection may be the interests of the national economy; state needs; economic interests of territorial entities; requirements for activities, quality of goods and services; interests of associations of groups of owners or owners in general; consumer interests [1].

Entrepreneurship is a manifestation of scientific and technical, economic (commercial) activity, organizational creativity and innovation. Modern Western literature distinguishes three functions of entrepreneurial activity: resource (mobilization of capital, labor, material and information resources); organizational (organization of production, sales, marketing, advertising), creative (innovation, generation and use of initiative, the ability to take risks) [2, p. 83].

Legal regulation is carried out based on a system of regulatory, protective and definitive norms contained in the sources of the national legal system. They determine the possible content and ways of doing business.

Establishing universally binding rules of conduct, the rules of law give participants in economic relations legal rights and responsibilities, determine the algorithms of representatives of government agencies in the processes of state regulation of entrepreneurship [3, p. 6].

As an element of the system of management and regulation of the national economy, entrepreneurship can perform the following functions, in particular: 1) filling the state budget and ensuring social development; 2) maintenance of those areas of activity that are not beneficial to the private sector, as well as the preservation of strategically important enterprises in state subordination; 3) mitigation of cyclical fluctuations of the economy and promotion of gradual increase of national production; 4) regulation of the price mechanism, especially with regard to the production and consumption of public goods; 5) prevention of monopoly in all its manifestations; 6) development of the country's innovation potential by investing in areas with a prolonged effect; 7) guaranteeing the economic security of the country; 8) creating an image for foreign partners of an economically stable and strong state $[4, \mathrm{p} .10]$. 


\section{Part 1. Legal consolidation of entrepreneurial activity, its essence}

In accordance with the Constitution of Ukraine (hereinafter referred to as the $\mathrm{CU}$ ) exclusively, the laws of Ukraine determine the legal basis and guarantees of entrepreneurship; competition rules and antitrust regulations; principles of civil liability; acts that are crimes, administrative or disciplinary offenses, and responsibility for them (paragraphs 8, 22 of Article 92).

In addition to the above, there should also be noted Art. 42 of the Criminal Code, according to which everyone has the right to entrepreneurial activity, which is not prohibited by law. Entrepreneurial activity of deputies, officials and servants of state authorities and local governments is limited by law.

The state provides protection of competition in business. Abuse of monopoly position in the market, illegal restriction of competition and unfair competition are not allowed. Types and limits of monopoly are determined by law [5].

The main normative act that enshrines the regulation of entrepreneurial activity is the Economic Code of Ukraine (hereinafter referred to as the ECU). A separate Chapter entitled «Economic commercial activity (entrepreneurship)» regulates the outlined issues. Thus, in particular, Art. 42 provides the concept of entrepreneurship. The latter is understood as an independent, proactive, systematic, economic activity carried out by economic entities (entrepreneurs) at their own risk in order to achieve economic and social results and profit [6].

In addition, this chapter also establishes the principles of entrepreneurial activity, organizational forms of entrepreneurship, the right to hire workers and social guarantees for the use of their labor, general guarantees of entrepreneurs' rights, issues of state support for entrepreneurship, cessation of entrepreneurial activity and more.

The principles of entrepreneurial activity define the following: entrepreneurship is carried out on the basis of free choice of types of entrepreneurial activity; independent formation by the entrepreneur of the program of activity, a choice of suppliers and consumers of the made production, attraction of logistical, financial and other types of resources, the use of which is not limited by law, setting prices for products and services in accordance with the law; free employment of employees by the entrepreneur; commercial calculation and own commercial risk; free disposal of profits remaining with the entrepreneur after payment of taxes, fees and other payments provided by law; independent implementation of foreign economic activity by the entrepreneur, the use by the entrepreneur of his or her share of foreign exchange earnings at its discretion (Article 44).

Entrepreneurship in Ukraine is carried out in any organizational forms provided by law, at the choice of the entrepreneur. The procedure for the creation, state registration, activity, reorganization and liquidation of business entities of certain organizational forms is determined by this Code and other laws. With regard to citizens and legal entities, for which entrepreneurial 
activity is not the main one, the provisions of this Code apply to that part of their activity which is entrepreneurial in nature (Article 45).

Art. 46 of the Economic Code establishes general guarantees of the rights of entrepreneurs, according to which the state guarantees all entrepreneurs, regardless of their chosen organizational forms of entrepreneurial activity, equal rights and equal opportunities to attract and use logistical, financial, labor, information, natural and other resources. Providing the entrepreneur with material and technical and other resources, which are centrally distributed by the state, is carried out in order to perform supplies, works or services by the entrepreneur for priority state needs.

The state guarantees the inviolability of property and protects the property rights of the entrepreneur. Withdrawal by the state or local self-government bodies from the entrepreneur of fixed and working capital, other property is allowed in accordance with Article 41 of the Constitution of Ukraine on the grounds and in the manner prescribed by law. Damages caused to an entrepreneur as a result of violation of his or her property rights by citizens or legal entities, state authorities or local self-government bodies shall be reimbursed to the entrepreneur in accordance with this Code and other laws. An entrepreneur or a citizen who works for an entrepreneur for hire, in cases provided by law, may be involved in the performance of state or public duties during working hours, with compensation to the entrepreneur for the relevant losses by the body that makes such a decision. Disputes about damages are resolved by the court.

Establishment and abolition of benefits and advantages in economic activity of certain categories of business entities is carried out in accordance with the Economic Code and other laws, in particular the Law «On Innovation» dated March 31, 2005. This law defines the legal, economic and organizational principles of state regulation of innovation in Ukraine, establishes forms of state incentives for innovation processes and aims to support economic development through innovation. According to it, business entities of all forms of ownership that implement innovative projects in Ukraine receive state support. The main legal means regulating the activities of economic entities listed by the ECU (Article 12) also include licensing, patenting of certain types of economic activities and its quotas; certification and standardization; application of standards and limits, regulation of prices and tariffs; providing investment, tax and other benefits, providing subsidies, compensations, targeted innovations and subsidies [2, p. 84].

In turn, the Civil Code of Ukraine (hereinafter referred to as the CCU) also plays an important role [7]. It regulates issues that arise in the course of business activities, including contracts of sale, supply and other forms of exchange, general and construction contracts, transportation of goods and more. According to the Law of Ukraine «On Entrepreneurship» [8], the latter is defined as a direct independent, systematic, at their own risk activities for production, performance of works, provision of services for profit, which are 
carried out by individuals and legal entities registered as business entities in the manner prescribed by law (Article 1).

Entities of entrepreneurial activity (entrepreneurs) may be: citizens of Ukraine, other states, stateless persons, not limited by law in legal capacity; legal entities of all forms of ownership; associations of legal entities operating in Ukraine under the terms of the production sharing agreement (Article 2).

The law includes state registration of entrepreneurship as a condition for carrying out business activities. The state registration of business entities, except for associations of legal entities operating in Ukraine under the terms of production sharing agreements, is carried out in the executive committee of the city, district city council or in the state administration of the district cities of Kyiv and Sevastopol (hereinafter referred to as the state registration authorities) at the location or place of residence of the subject, unless otherwise provided by law. It is prohibited to register business entities, the names of which contradict the requirements of part three of Article 2 of this Law. Information on registered business entities is entered into the Register of Business Entities. The procedure for its conduct is determined by the Cabinet of Ministers of Ukraine.

The issue of entrepreneurship is also regulated by the laws of Ukraine: «On Protection of Economic Competition», «On Consumer Rights Protection», «On Licensing of Economic Activities», «On Protection Against Unfair Competition», «On the Main Principles of State Supervision (Oversight) in the Area of Commercial Activity», "On the National Program on Promotion of Development of Small Business in Ukraine», «On Foreign Economic Activities», «On Banks and Banking», etc.

The system of legal bases of entrepreneurship also contains bylaws, i.e., regulations of the competent authorities, adopted in accordance with the law, on its basis and for its implementation. The organization of specialized executive bodies in the field of business regulation is based on relevant provisions: regulations that regulate the procedures of formation, structural organization, financial and material support, competence, hierarchical subordination of relevant structures [9, p. 9].

When studying the issue of entrepreneurship in the literature, scientists interpret this concept as: 1) independent, proactive economic and financial activities of citizens aimed at making a profit (income), which is carried out on its own behalf, at their own risk and under their personal property responsibility or on behalf and under the property responsibility of a legal entity - enterprise [10, p. 7]; activities based on a combination of interest, means, materials, labor in such a way that their total value increases with the effect [11, p. 138]; type of economic behavior of entrepreneurs to organize production in order to make a profit and social effect [12]. We still support the last proposed concept.

According to V. Dobrovolska, it is necessary to develop an effective legal framework for regulating the activities of economic entities for the successful 
development of entrepreneurship in Ukraine. The state must develop a flexible system of taxation of entrepreneurs in order to create favorable conditions for them to receive a stable income. State support for entrepreneurs should include their legal protection, the creation of an appropriate information and consulting framework, promoting investment in the development of domestic entrepreneurship [13].

Instead, N.I. Diachenko and A.Ye. Hryhorenko note that the legal provision of enterprise regulation in Ukraine needs to be improved at the state, regional and local levels [1].

In particular, at the state level: 1) ensuring equal rights and creating equal opportunities for entrepreneurs of different levels to access logistical, financial, labor, information, natural and other resources; 2) provision of material and technical and other resources that are centrally distributed by the state (carried out only if the entrepreneur performs work and supplies for state needs); 3) ensuring the inviolability of property and ensuring the protection of property rights of entrepreneurs; 4) compensation for damages caused to the entrepreneur as a result of violation by citizens, legal entities and state bodies of his or her property rights, protected by law, in accordance with applicable law; 5) implementation of measures to eliminate restrictions that hinder the development of entrepreneurial activity; 6) ensuring the consistency and stability of regulatory and legal regulation of business activities; 7) practical implementation of the state system of support for all areas of entrepreneurship (completion of proper market infrastructure; implementation of financial support for entrepreneurship, including the formation of start-up capital; creating conditions for foreign economic activity; launching a progressive training system for modern business; entrepreneurship) [1].

At the regional level: 1) creation of favorable organizational and economic conditions for the development of entrepreneurship (provision of land, transfer of state property to the entrepreneur, necessary for business activities); 2) stimulating the modernization of technology, innovation, development of new products and services through economic levers (targeted subsidies, tax benefits, etc.); 3) providing targeted loans and other types of assistance to entrepreneurs to the required extent; 4) implementation of scientific and technical, economic and social regional programs; 5) simplification of the procedure for creation, registration and liquidation of business entities; 6) reduction of the list of types of business activities that are subject to licensing and patenting, require obtaining certificates and any other permits to conduct business activities; 7) limitation of inspections and control over the activities of business entities; 8) simplification of the procedure of customs clearance of goods in the implementation of exportimport operations [1].

At the local level: 1) ensuring the protection of competition in business, consumer protection, control over the quality and safety of products and all types of services and works; 2) setting prices and pricing rules in possible 
cases; targeted grants; the size of economic sanctions; 3 ) conclusion of contracts for works and supplies for state needs of formation of infrastructure of support and development of small business, organization of state training, retraining and advanced training of personnel for small business entities taking into account the needs of the territorial community; 4) improvement of the simplified system of taxation, accounting and reporting; 5) intensification of financial and credit support for small businesses at the suggestion of local governments [1].

The position of Ya. V. Slyvchenko should also be noted, according to which the ways to improve state regulation of business development in Ukraine should be: 1) improvement of existing legal acts regulating business activities in order to eliminate internal legal contradictions and eliminate provisions that hinder development entrepreneurship; 2) further implementation of the state regulatory policy in the field of economic activity in order to create a favorable business environment; 3) intensification of financial and credit and investment support for entrepreneurship; 4) promoting the creation of infrastructure for business development; 5) improvement of the tax system, which would provide a sufficient amount of payments to the budgets of all levels, the efficient functioning of the country's economy, a fair approach to taxation of all categories of taxpayers; 6) the formation of a proper legal environment for the development of innovative and scientific and technical activities, increasing the motivation of entrepreneurs to high-performance and high-quality activities through improving the system of economic incentives by amending tax and customs legislation [14].

Most of the above points already exist, but they are declarative in nature. We believe that the problem can be solved by developing a certain legal mechanism by which the outlined changes will be really effective and efficient.

Negative factors in this area, according to L. Sh. Mamatova, include: uncertainty about the priority of legislation to regulate business activities; complexity and volume of the regulatory framework; constant changes and additions to the laws; instability and internal contradiction of legislative acts and their separate norms concerning regulation of business relations; disproportion in the ratio of laws and bylaws, their declamation; lack of mechanisms for their implementation in many laws; underestimation of issues related to the realization of human and civil rights and freedoms guaranteed by international conventions that have been signed and ratified by Ukraine [15, p. 35].

The content of the effectiveness of laws on legal support of entrepreneurial activity is the implementation of a set of professionally developed legal means to achieve the following goals: increasing the capacity of the economy, saturation of the domestic market with consumer goods of national production, ensuring social protection of citizens, the conquest of foreign 
markets, global economic influence, the skilled work of the administration in the field of state regulation of this area. For the successful development of entrepreneurship in Ukraine, it is necessary to develop an effective legal framework for regulating the activities of economic entities. The state must develop a flexible system of taxation of entrepreneurs in order to create favorable conditions for them to receive a stable income. State support for entrepreneurs should include their legal protection, the creation of an appropriate information and consultation base, assistance in attracting investment in the development of domestic entrepreneurship.

The main shortcomings of the legal support of entrepreneurship in Ukraine are: ambiguity, instability and inconsistency of the current legal framework of entrepreneurship; practically non-functioning nature of many legal acts, very low executive discipline in relation to normative legal documents; the presence in the legislation of many vague norms, which, if desired, can be subjected to any interpretation; unfounded legal restrictions and requirements contained in certain regulations [15, p. 36].

The ways to improve state regulation of business development in Ukraine should be: improvement of existing legal acts regulating business activities in order to eliminate internal legal inconsistencies and repeal the provisions that hinder the development of entrepreneurship; further implementation of state regulatory policy in the field of economic activity in order to create a favorable business environment; intensification of financial, credit and investment support for entrepreneurship; promoting the creation of business development infrastructure; improvement of the tax system, which would provide a sufficient amount of payments to the budgets of all levels, efficient functioning of the country's economy, a fair approach to taxation of all categories of taxpayers; formation of a proper legal environment for the development of innovation and scientific and technical activities, increasing the motivation of the entrepreneur to high-performance and high-quality activities through improving the system of economic incentives by amending tax and customs legislation [15, p. 37].

In general, the improvement of legal support for business should be carried out in the following areas: 1) the first direction is mediated by the need to form the public opinion in society by means of agitation, encouragement, persuasion, that prosperous entrepreneurs are the basis of material prosperity of all other segments of the population; 2) the second direction is related to the need to ensure the functioning of a market economy by providing a legal framework and social atmosphere that contribute to the successful development of entrepreneurial activity and create conditions for integrating entrepreneurs into the common space of social responsibility and maintaining stability of economic reforms and implementation of socio-economic development programs; 3) the third direction involves the reform of regulatory relations between the state and business entities in order to overcome the opposition to regulatory and administrative reform and inertia 
by public administration bodies that have powers in the field of regulatory policy [15, p. 37].

Improvement of legal support requires improvement of: norms that determine the legal status of business entities in the course of their implementation of economic competence and optimization of state regulation; the essence, content and effectiveness of laws; determining the content and effectiveness of administrative and economic liability; legal mechanism for ensuring the implementation and protection of economic and social rights and interests of entrepreneurs; legal bases of administrative activity of public administration; legal measures to eradicate corruption in the economic and public spheres; the order of balance of state and public interests with the interests of business entities (public law with private law); organization of measures for adaptation of national legislation in the field of business to the European legislation; basic provisions on the legal regime of ownership (adoption of the law on property); economic and legal mechanism of legalization of shadow capital, shadow activity, and shadow economy [15, p. 38].

\section{Part 2. Foreign experience and entrepreneurship in a pandemic, special regime of economic activity}

In all countries of the world, one of the main functions of state regulation of entrepreneurial activity is the function of business support, aimed at creating conditions and mechanism for providing subsidies and other forms of financial assistance designed to promote certain industries, regions of the country, and sometimes individual entrepreneurs [16, p. 262].

The system of tax incentives for business development in economically developed countries includes various tax benefits: depreciation, benefits to stimulate research and development, benefits for the formation of reserve funds, tax credits, tax holidays, etc. [17].

Considering foreign experience, it can be argued that a particularly effective factor in the formation and development of an efficient economy is the formation of socially oriented entrepreneurship, the main purpose of which is profitable enterprises without harming society and the environment. Socially oriented model of entrepreneurship will allow companies to meet modern value orientations of society, the needs of labor collectives, without contradicting the economic orientations of business owners [18, p. 106].

One of the effective means of stimulating the development of the business sector in the EU is the tax policy of the state. For example, in the United Kingdom, individual firms are not required to register, and taxes are paid based on declaring the individual income of the firm's members.

And even if the firm is registered with the government, taxes are paid only after the firm has become active in the market and found its customers. In general, the amount of taxes paid by small enterprises are smaller, and the taxation procedure is much simpler than for large enterprises. In addition, 
progressive corporate income taxation is also used: tax rates for lower-income corporations are lower than for high-income corporations [19, p. 53].

In Ukraine, in connection with the global quarantine (COVID 19), several regulations have been adopted to mitigate and simplify to some extent doing business. Thus, today, the Verkhovna Rada has already adopted two «anticoronavirus» laws, which, among other things, provide for temporary «easing» for small and medium-sized businesses, in particular, for individual entrepreneurs. These are bills No.3220 «On Amendments to the Tax Code of Ukraine and Other Laws of Ukraine on Support of Taxpayers for the Period of Measures to Prevent the Occurrence and Spread of Coronavirus Disease (COVID-19)» dated March 17, 2020 and No.3275 «On Amendments to certain legislative acts aimed at providing additional social and economic guarantees in connection with the spread of coronavirus disease (COVID2019)» dated March 30, 2020. The latest document extends a few provisions of the previous one and provides additional steps to support business.

In particular, the limits for entrepreneurs working on the simplified taxation system were increased: for the 1st group («self-employed» individual entrepreneurs who do not involve employees) the annual income limit was increased from $300000 \mathrm{UAH}$ to 1 million $\mathrm{UAH}$, for the 2nd group (sole proprietors who employ no more than 10 employees) - from 1.5 to 5 million $\mathrm{UAH}$, for the 3rd group (legal entities - small businesses of any organizational and legal form) - from 5 to 7 million UAH.

From March 01 to April 30, 2020, individual entrepreneurs are exempt from paying a single social contribution. For businesses that have paid this contribution in advance for March and April, these funds are automatically credited as payment for subsequent periods. Moreover, if desired, you can even return the money (according to the procedure provided by the order of the Ministry of Finance No.6 dated June 16, 2016).

Due to the quarantine, the legislator has postponed the payment of personal income tax from August 01 to October 01, 2020. Another decision concerns the tax benefits of charitable contributions aimed at combating the coronavirus. Such contributions are exempt from income tax, and individuals may include these amounts in the personal income tax rebate.

In addition, the issues of fiscal easing, partial unemployment benefits, credit vacations and a «voluntary» approach to the abolition (reduction) of rent are also regulated [20].

In addition, it should be noted that the Verkhovna Rada adopted the Law «On Amendments to the Tax Code of Ukraine and Other Laws of Ukraine on Additional Support to Taxpayers for the Period of Measures to Prevent the Occurrence and Spread of Coronavirus (COVID-19)».

The law extended tax benefits and simplified administrative procedures until the end of quarantine. The law extended the period of non-application of penalties for violations of tax legislation from March 01, 2020 to the last calendar day of the month, in which the government announces the end of the 
quarantine; term of non-accrual of interest; moratorium on documentary and factual inspections; the term of the Law of Ukraine "On Simplification of Procedures for Reorganization and Capitalization of Banks». The law exempts from payment of SSC for entrepreneurs until May 31, 2020.

The law amended section XX of the Tax Code of Ukraine, which provides «Temporarily, the amount of personal income tax withheld from income in the form of salary supplements, determined in accordance with subparagraph 2 of paragraph 5 of section II of the Law of Ukraine «On Amendments to the Tax of the Code of Ukraine and other laws of Ukraine on support of taxpayers for the period of measures aimed at preventing the occurrence and spread of coronavirus disease (COVID-19)», and accrued for the period of May 01-30, 2020 and June 01-30, 2020, medical and other employees of health care institutions of state and / or communal property, that directly engaged in the elimination of the epidemic and the implementation of measures to prevent the spread of acute respiratory disease COVID-19 caused by coronavirus SARS CoV-2, and the treatment of patients with acute respiratory disease COVID-19 caused by coronavirus SARS CoV-2 the executive body that implements the state policy in the field of health care shall compensate such employees in full at the expense of the state budget of Ukraine. The procedure for payment of such monetary compensation shall be approved by the Cabinet of Ministers of Ukraine».

The law stipulates that «For the period from April 2, 2020, the total monthly (annual) taxable income of a personal income of a taxpayer does not include income in the form of partial unemployment benefits for the quarantine period established by the Cabinet of Ministers of Ukraine to prevent the spread of acute respiratory disease COVID-19 disease caused by coronavirus SARS-CoV-2, which are paid (provided) by the employer in accordance with Article 47-1 of the Law of Ukraine «On Employment».

The law stipulates that «Temporarily, for the period up to the last calendar day of the month (inclusive), in which the quarantine established by the Cabinet of Ministers of Ukraine throughout Ukraine ends in order to prevent the spread of coronavirus disease in Ukraine (COVID-19), the deadlines established:

Article 56 of this Code (regarding the procedure of administrative appeal), on complaints of taxpayers (except for complaints on the legality of declaring the value added tax claimed from the budget and / or the negative value of value added tax) received (will be received) ) on the last calendar day of the month (inclusive), which terminates the quarantine established by the Cabinet of Ministers of Ukraine throughout Ukraine in order to prevent the spread of coronavirus disease in Ukraine (COVID-19), and / or not considered as of March 18, 2020. Such suspension does not give rise to any consequences provided for in Article 56 of the Tax Code of Ukraine; Articles 52-53 of this Code on the provision of individual tax advice by the supervisory authorities in writing; Articles 73 and 78 of this Code on the provision of taxpayers' 
responses to requests from regulatory authorities (except for requests of controlling bodies regarding the legality of declaring the value added tax claimed for reimbursement from the budget and / or from the negative value from the value added tax) received by taxpayers on the last calendar day of the month (inclusive), in which the quarantine established by the Cabinet of Ministers of Ukraine throughout Ukraine in order to prevent the spread of coronavirus disease in Ukraine (COVID-19), is coming to an end.

From the first calendar day of the month following the month, in which the quarantine to prevent the spread of coronavirus disease in Ukraine (COVID-19), established by the Cabinet of Ministers of Ukraine throughout Ukraine, ends, the period suspended in accordance with this paragraph shall continue from considering the time elapsed before such a stop» [21].

In the conditions of constant change of business rules, reorientation of economy, financial and economic crisis, emergence of various epidemics, it is necessary to reformat approaches to legal regulation of economic activity, and also establishment of special regime of economic activity according to real conditions of today.

Both the legislation of Ukraine and the legal norms of most foreign countries provide for the establishment of various benefits and prohibitions, which are established either for the type of economic activity, or for a certain range of business entities, or special conditions for doing business in a certain area. In order to increase investment attractiveness, create new jobs, support the «depressed» regions or sectors of the economy, incentive remedies are used. In case of necessity of strengthening of the state control over conducting economic activity - the restrictive special regime of economic activity is entered. In addition, sometimes there is a need to establish certain strict restrictions and controls and, at the same time, to create attractive economic conditions. In this case, both restrictive and incentive measures are applied simultaneously, a restrictive-incentive special regime of economic activity is introduced [24, p. 39].

For the first time in the legislation of Ukraine, the concept of «special regime of economic activity» was introduced by the CCU. The Code provides for various types of special management regimes (Section 8 of the Civil Code, Chapters 39-41), but does not define the very concept of special regime of economic activity, its features, means of state regulation, which are an integral part of any legal regime, delimitation criteria, i.e., the basic tools of the special regime of economic activity are not actually enshrined in law.

Types of special regimes of economic activity include: special regime of economic activity in special (free) economic zones; concessions; exclusive (maritime) economic zone of Ukraine; on the state border of Ukraine; in sanitary protection and other protection zones, territories and objects that are specially protected; special regime of economic activity in certain sectors of the economy; priority development areas; special regime of economic activity 
in a state of emergency, environmental emergency; special regime of economic activity in martial law.

A serious shortcoming of the legal regulation of special regime of economic activity, in our opinion, is the impossibility of modeling new species with special regimes not provided by economic legislation. Analysis of the norms of the CCU gives every reason to conclude that the list of special regimes of economic activity is closed. In addition, Part 1 of Art. 418 of the Civil Code of Ukraine enshrines guarantees of participants in special regimes of economic activity, which are that the introduction of special regimes of economic activity not provided for in this Code, which establishes restrictions on the rights of business entities is not allowed.

A detailed analysis of the norms of the CCU allows us to state categorically that the current business situation does not fall under its regulation under a special regime. However, in fact, the restrictions that have been introduced today are real signs of a special restrictive regime of economic activity. That is why we propose to make appropriate changes to national legislation in order to make such restrictive measures legal, as well as to establish a balanced mechanism for balancing the interests of the state and entrepreneurs in today's difficult conditions for the world.

\section{Conclusions}

Today, there is a significant over-regulation of entrepreneurial activity and the lack of transparent mechanisms of interaction between public authorities and entrepreneurs, which leads to negative trends in the development of entrepreneurship.

Looking at the recent changes in our country, including during the global pandemic caused by coronavirus virus, we can see that the state is only at the beginning of changes in the regulation of entrepreneurship.

To develop and support small and medium-sized businesses, it is necessary to develop an effective implementation mechanism by the state, starting with the regulation and effectiveness of regulations and ending with financial assistance and a simplified tax system. In order to implement this thesis, we consider it appropriate to turn to the foreign experience of developed countries that have developed effective mechanisms for their own economies. It is necessary to minimize over-regulation, which restricts competition, the mobility of resources from one area to another, which reduces the overall achievements in the economic sphere; to establish tax benefits not only for the pandemic period, but on a permanent basis, including tax credits, tax holidays, etc.

It should also be noted that the basis of entrepreneurship in Ukraine should be the activities of enterprises without harming society in the environment, which will help to prevent health damage, ensure environmental safety, and protect the environment from harmful effects. This issue is disclosed in more detail in these works [22; 23]. Increasing economic capacity, saturation of the 
domestic market with consumer goods of national production, the conquest of foreign markets and global economic influence - all this should become the closest vector for the economy of our country.

\section{References:}

1. Djačenko N. I., Hryhorenko A. Je. Problemy pravovoho zabezpečennja rehuljuvannja pidpryjemstvom v Ukrajini (2007) [Problems of legal support of enterprise regulation in Ukraine]. Proceedings of the Nauka ta praktyka 2007 (Ukraine, Poltava, February 11-15, 2007). Available at: https://www.pdaa.edu.ua/np/pdf/4.pdf (accessed 1 July 2020).

2. Skorytskyi A. M. Analiz pravovoho rehuliuvannia pidpryiemnytskoi diialnosti v Ukraini (2014) [Analysis of legal regulation of business activity in Ukraine]. Nashe pravo, no 1, pp. 82-88.

3. Bavyko O. Ye. Strukturno-funktsionalna model pravovoho rehuliuvannia pidpryiemnytskoi diialnosti v Ukraini (2017) [Structural and functional model of legal regulation of business activity in Ukraine]. Visnyk Donetskoho natsionalnoho universytetu ekonomiky i torhivli im. Mykhaila Tuhan-Baranovskoho. Seriia: Ekonomichni nauky, no 2, pp. 5-13.

4. Melnyk A., Tynska I. Derzhavne pidpryiemnytstvo $\mathrm{v}$ umovakh transformatsii upravlinnia natsionalnoiu ekonomikoiu (2014) [State entrepreneurship in the conditions of transformation of national economy management]. Visnyk Ternopilskoho natsionalnoho ekonomichnoho universytetu, vol. 2, pp. 7-19.

5. Konstytutsiia Ukrainy: Zakon Ukrainy (1996) [Constitution of Ukraine] Vidomosti Verkhovnoi Rady Ukrainy vid 23.07.1996, no 30, Art. 141.

6. Hospodarskyi kodeks Ukrainy: Zakon Ukrainy (2003) [Commercial Code of Ukraine]. Vidomosti Verkhovnoi Rady Ukrainy vid 02.05.2003, no 18, Art. 144.

7. Tsyvilnyi kodeks Ukrainy: Zakon Ukrainy (2003) [Civil Code of Ukraine]. Vidomosti Verkhovnoi Rady Ukrainy vid 03.10.2003. no 40. Art. 356.

8. Pro pidpryiemnytstvo: Zakon Ukrainy (1991) [On Entrepreneurship] Vidomosti Verkhovnoi Rady URSR vid 02.04.1991, no 14, Art. 168.

9. Bavyko O. Ye. Strukturno-funktsionalna model pravovoho rehuliuvannia pidpryiemnytskoi diialnosti v Ukraini (2017) [Structural and functional model of legal regulation of business activity in Ukraine]. Visnyk Donetskoho natsionalnoho universytetu ekonomiky i torhivli im. Mykhaila Tuhan-Baranovskoho. Seriia: Ekonomichni nauky, no 2, pp. 5-13.

10. Pokropyvnyi S. F., Kolot V. M. (1998) Pidpryiemnytstvo: stratehiia, orhanizatsiia, efektyvnist [Entrepreneurship: strategy, organization, efficiency]. Kyiv: KhNEU. (in Ukrainian)

11. Malik M. Y. Pidpryiemnytstvo u rozvytku ahrarnoho rynku (2007) [Entrepreneurship in the development of the agricultural market]. Ekonomika APK, no 11, pp. 138-149.

12. Varnalii Z. S. (2006) Osnovy pidpryiemnytstva [Fundamentals of entrepreneurship]. Kyiv: Znannia-Pres. (in Ukrainian)

13. Dobrovolska V. Zasoby derzhavnoho rehuliuvannia pidpryiemnytskoi diialnosti (2006) [Means of state regulation of business activity]. Pidpryiemnytstvo, hospodarstvo $i$ parvo, no. 2, pp. 94-99.

14. Slyvchenko Ya. V. Shliakhy vdoskonalennia derzhavnoho rehuliuvannia rozvytku pidpryiemnytstva v Ukraini (2015) [Ways to improve state regulation of entrepreneurship in Ukraine]. Proceedings of the Public administration in Ukraine: a reform strategy 
(Ukraine, Kharkiv, September 30th, 2015). Available at: http://www.kbuapa.kharkov.ua/ e-book/conf/2015-5/doc/4/04.pdf (accessed 1 July 2020).

15. Mamatova L. Sh. Pravove zabezpechennia pidpryiemnytskoi diialnosti v Ukraini (2018) [Legal support of business activity in Ukraine] Reporter of the priazovskyi state technical university. Section: Economic sciences, 2018, issue 35, pp. 33-40.

16. Pavlishenko I. B., Bosyk O. V. Derzhavne rehuliuvannia pidpryiemnytstva v Ukraini: napriamky ta priorytety (2007) [Government regulation of enterpreneurship in Ukraine: ways and priorities]. Naukovyi visnyk. Zbirnyk naukovo-tekhnichnykh prats. Ekonomika, planuvannia ta upravlinnia v lisovyrobnychomu kompleksi, vol. 17.1, pp. 258-263.

17. Bila I. S., Salatiuk N. M. Svitovyi dosvid derzhavnoho rehuliuvannia pidpryiemnytstva (2014) [World experience of state regulation of entrepreneurship]. Problemy ekonomiky, no 1, pp. 26-30.

18. Kashuba O. M. Pidpryiemnytstvo v Ukraini: problemy i perspektyvy rozvytku (2015) [Entrepreneurship in Ukraine: problems and prospects of development]. Ekonomika ta derzhava, no 6, pp. 103-106.

19. Komarnytskyi I. M. (2000) Orhanizatsiino-ekonomichni mekhanizmy rozvytku pidpryiemnytstva [Organizational and economic mechanisms of business development]. Uzhhorod: «Patent». (in Ukrainian)

20. Ukrinform. Yak vyzhyty FOPam pid chas karantynu (2020) [How to survive individual entrepreneurs during quarantine]. Available at: https://www.ukrinform.ua/ rubriceconomy/3000269-karantinna-pidtrimka-fopiv-efektivna-ci-ak-mertvomu-priparka.html (accessed 1 July 2020).

21. Informatsiina pidtrymka biznesu [Business information support]. Available at: https://epo.org.ua/covid19/ (accessed 1 July 2020).

22. Savchuk O. O. Pravove rehuliuvannia ekolohichnoho pidpryiemnytstva v Ukraini (2019) [Legal regulation of ecological entrepreneurship in Ukraine] Proceedings of the III International Scientific Conference Anti-Crisis Management: State, Region, Enterprise (France, Le Mans, November 22th, 2019). Baltija Publishing, p. 136-138.

23. Savchuk O. O. (2018) Pidpryiemnytstvo u sferi lisokorystuvannia yak odyn iz shliakhiv innovatsiinoho rozvytku [Entrepreneurship in the field of forest use as one of the ways of innovative development]. Pravo ta innovatsii, no 1(21), pp. 52-55.

24. Matvieieva, A. V. (2018) Spetsialnyi pravovyi rezhym hospodariuvannia: poniattia i vydy [Special regime of economic activity: concepts and types]. Pravo ta innovatsii, no 4(24), pp. 39-44. 